\title{
Endoscopic assisted supraorbital approach for management of extensive and/or complicated frontal sinus lesions.
}

\author{
Original \\ Article \\ Nabil Galal', Ehab Abou Zaid ${ }^{2}$,Ahmed Ali Ibrahim ${ }^{3}$,El-Sayed Ragab Attia ${ }^{4}$ \\ Department of Otorhinolaryngology, ${ }^{1,2}$ Cairo University, ${ }^{3}$ Alexandria University, ${ }^{4}$ Balteem \\ Specialized Hospital, Egypt.
}

\begin{abstract}
Background: Successful surgical management of frontal sinus disease remains a significant challenge for rhinologists. The purely endoscopic/endonasal approach has limitations, especially in patients with complex frontal sinus pneumatization patterns as well as alterations in anatomy. Supraorbital approach that provides improved access and visualization of these challenging anatomical regions might enhance the management of anterior skull base and extensive frontal sinus lesions. Aim: To evaluate the efficacy and safety of the supraorbital approach for management of extensive frontal sinus lesions. Patients and Methods: The study was conducted on 20 patients with extensive frontal sinus pathologies using the supraorbital approach via the eyebrow incision at Kasr Al-Ainy Hospital and Alexandria Main University Hospital in 4 years (from March 2015 till March 2019). The patients were followed-up for 24 months.

Results: Supraorbital approach used alone or in multiportal combination with endoscopic sinus surgery to safely and effectively treat extensive frontal sinus lesions. The only complication that occurred was parasthesia in the forehead due to supraorbital nerve injury in one patient (5\%) which is resolved within 6 months post-operatively. No late complications or evidence of recurrence of the disease were developed till the end of the follow-up period.

Conclusion: The supraorbital approach is a safe, direct and minimally disruptive approach to the anterior skull base and frontal sinus lesions and should be considered as an alternative to more extensive craniofacial approaches for selected pathologies of the frontal sinus and the anterior skull base.
\end{abstract}

Key Words: Anterior skull base, frontal sinus, supraorbital Approach.

Received: 4 June 2021, Accepted: 19 August 2021

Corresponding Author: El-Sayed Ragab Attia, MD, Balteem Specialized Hospital, Specialized Medical Centers, Egypt. Tel.: 01287999536, E-mail: dr.sayedatya@yahoo.com

ISSN: 2090-0740, 2021

\section{INTRODUCTION}

The successful surgical management of frontal sinus diseases remains a significant challenge for rhinologists. A complex pneumatization pattern of frontal recess cells obscures the drainage pathway of the frontal sinus from direct endoscopic view ${ }^{[1]}$.

To address the anatomic challenges of approaching complex frontal sinus and the anterior skull base lesions, numerous craniofacial approaches have been developed. These approaches carry risks, and while they may be tolerated for resection of malignant pathology, they may not be considered acceptable for benign pathology or malignant disease with less extensive anatomic involvement. Minimally invasive approaches, such as endonasal endoscopy and keyhole craniotomies, are increasingly being used to reduce the risks associated with such approaches ${ }^{[1]}$.

Although endonasal approaches have reduced the morbidity of accessing pathology in the nasal cavity, they have limitations when dealing with the anterior skull base, such as the inability to perform microsurgical dissection with complex lesions, adequate dural closure, and access to the anterior cranial fossa laterally over the orbits away from the midline, as well as limited working space when multiple surgeons are working ${ }^{[2]}$.

The Supraorbital approach (SO) improves access and visualisation of these difficult anatomical regions, allowing for more effective management of the anterior skull base and extensive frontal sinus lesions ${ }^{[3]}$.

\section{PATIENTS AND METHODS:}

The current study was conducted on 20 patients who were scheduled for endoscopic supraorbital approach for management of extensive and/or complicated frontal sinus lesions which underwent in the period from March 2015 till March 2019. The patients were followed-up for 24 months. 
The patients were subjected to the following:

1) Preoperative:

- Full history taking.

- Physical examination to assess the patient's general condition

- Rhinological examination with angled endoscopes.

- Radiological Imaging Studies: Computed Tomography (CT) and/or high-resolution Magnetic Resonance Imaging (MRI).

- Laboratory tests: All routine investigations were requested.

- Ophthalmological examination: Fundus examination and visual field test for lesions affecting the eye.

- Informed consent before surgery.

\section{2) Intraoperative:}

- The surgical procedures adopted were purely supraorbital or combined with an endoscopic endonasal approach.

\section{3) Postoperative:}

- Serial endoscopic examinations every six months for six months.

- Follow-up CT and/or MRI Six months and a year after.

\section{Operative technique:}

\section{Patient Positioning and Preparation}

Patients are placed in a supine position with the head of the table raised up to $15^{\circ}$. The course of the supraorbital nerve must be respected to prevent complications. The incision is outlined and infiltrated with a mixture of lidocaine $2 \%$ and epinephrine. To protect the cornea, a lubricating ophthalmic ointment is applied to the eye, and a temporary tarsorraphy suture is placed. (Fig.1)

\section{Incision and Orbitofrontal Exposure}

The supraorbital approach starts with an eyebrow incision (ranging from one $\mathrm{cm}$ to five $\mathrm{cm}$ ). If the eyebrow is very thin, the skin incision can be made in an upper eyelid crease or a previous scar in the supraorbital area. After dissection of the subcutaneous tissue and periorbital muscles, the supraorbital neurovascular bundle is identified and released. Subperiosteal elevation of the frontalis muscle and forehead skin is widely performed to expose the frontal bone, if required. The orbital roof is exposed by releasing the periorbita by blunt subperiosteal dissection, making every effort to preserve the periorbita in continuity with the reflection of the orbital septum anteriorly, to avoid herniation of the orbital contents. Soft tissue retractors are placed along the incision to maintain the bony exposure. (Fig.1)

\section{Supraorbital Minicraniotomy}

The craniotomy is variably designed based on the type and location of the pathology to provide the most direct approach for instrumentation.

The craniotomy may be limited to the orbital roof or may be along the anterior wall of the frontal sinus. The entire anterior frontal sinus wall may be elevated as a single osteoplastic flap. The dissection within the frontal sinus is performed under direct and endoscopic visualization. The dissection is carried out with basic endoscopic sinus instrument. Simultaneous visualization and dissection through the craniotomy and endonasal "above and below" corridors can be performed to ensure continuity of the dissected areas to minimize skipped lesions. If access to the anterior skull fossa is required to assess the frontal dura and manage the intracranial lesions, a window is created through the posterior wall of the frontal sinus using a combination of diamond burrs, Kerrison punches, and bone rongeurs. (Fig.1)

\section{Reconstruction of Postsurgical Defect}

Reconstruction involves three stages: dural repair, bony reconstruction, and cosmetic closure of the incision. Dural reconstruction is performed either by direct suturing, with dural replacement grafts, fascia lata grafts, or pedicled pericranial flaps. Fibrin glue is used to reinforce the dural repair. The bone flap is then replaced and held in place with low-profile miniplates or sutures. When the defect in the bone is larger than one centimeter, we repair it with a titanium mesh. Finally, the incision is closed in a layered fashion and the skin is closed in a subcuticular way.

\section{Postoperative care}

To reduce periorbital swelling after surgery, the patient's head is inclined at a 30 degree angle. Artificial tears are liberally used. The incision is cleaned daily and ophthalmic antibiotic ointment is applied. At regular intervals, ice packs are applied (every four hours for two days).

\section{How to avoid complications}

Respecting anatomical landmarks, approach-related injury to the supraorbital nerve (dissection, compression) can be avoided. 
Avoid the excessive use of monocautery and bipolar coagulation during soft tissue dissection to minimize the risk of eyebrow depilation.

Retraction of the intraorbital content is performed with caution.

In the case of a "two-piece" bone flap, separate pieces should be reattached with titanium plates and screws.
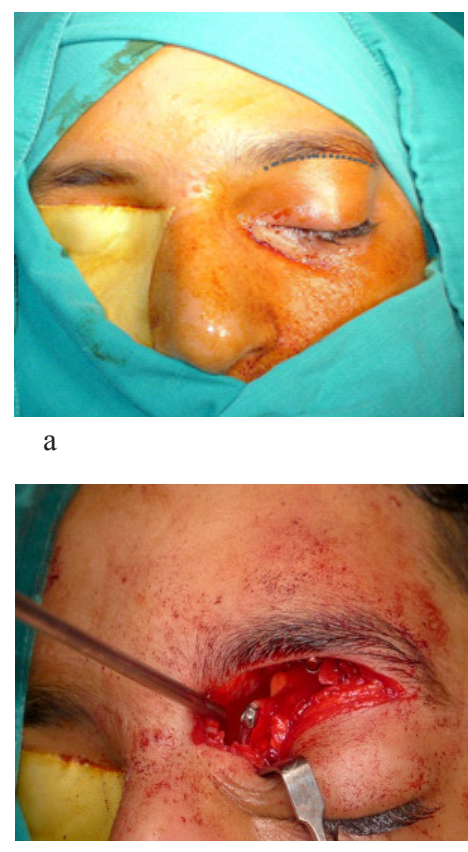
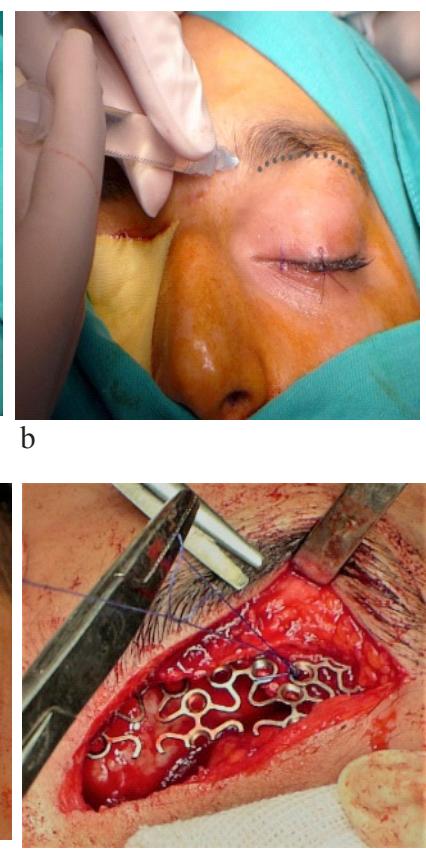

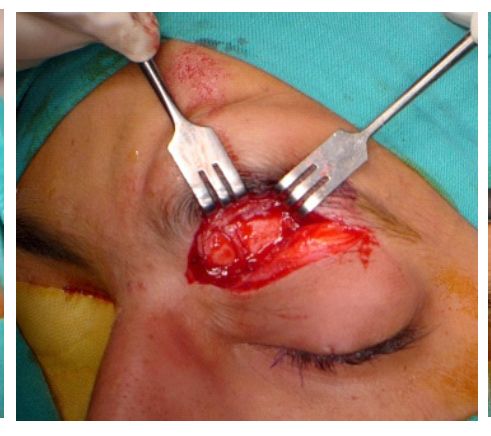

c

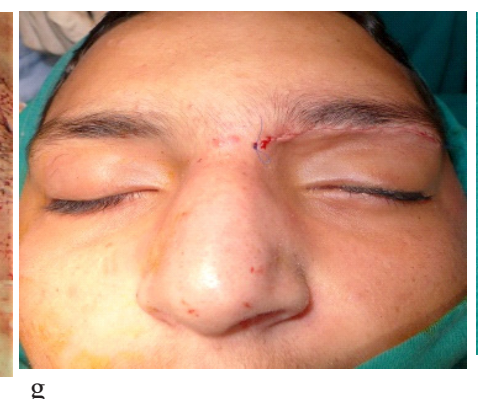

With meticulous closure of the skin using nonabsorbable subcuticular sutures, an optimal cosmetic outcome can be achieved.

Working with an experienced neuroanaesthesiologist is recommended.

Fig. 1: Supraorbital minicraniotomy: (a) eyebrow incisions and tarsorraphy (b) injection. (c) Dissection to expose the frontal bone. (d) Delivering of large osteoma. (e) The endoscope used to assess the drainage from above while suction used to ensure for patency from below. (f) The titanium mesh for reconstruction fixated with proline suture. (g) Closure of incision in subcuticular manner. (h) Large osteoma.

\section{RESULTS:}

The current study included 20 patients with frontal sinus pathologies, 16 of whom were males $(80 \%)$ and four of whom were females $(20 \%)$.

The age range was 9 to 66 years, with a mean age of 39.80 years.

The pathology of the frontal sinus was divided into three categories: inflammatory (60\%), neoplastic (20\%), and CSF leak (20\%).

The pure SO approach was used in nine patients $(45.0 \%)$, and the combined "above and below" approach was used in 11 patients (55\%).

According to the reconstruction used, the titanium mesh was used to reconstruct the anterior table defect in three cases (one case of osteoma and two cases of Pott's puffy tumor). According to the reconstruction used, the titanium mesh was used to reconstruct the anterior table defect in three cases (one case of osteoma and two cases of Pott's puffy tumor). In these cases, the anterior table was already partially eroded by the pathology and the defect after removal of the pathology was more than one centimeter, so we reconstructed it with a titanium mesh.

The posterior table defect was reconstructed in five cases; four cases of CSF and one case of IP (two cases were repaired using pericranial flap, fascia lata graft, fat, platelet-rich fibrin (PRF), and tissue glue, while the other three cases were reconstructed using fascia lata graft, fat, middle turbinate graft, surgicel, and tissue glue).

The only complication encountered was parasthesia due to supratrochlear and supraorbital nerve injuries in one patient (5\%) (\# pt.10) and there was no evidence of recurrence until the end of the follow-up period. 
Table 1: Summary table

\begin{tabular}{|c|c|c|c|c|c|c|}
\hline No & $\begin{array}{l}\text { Age } \\
\text { ys }\end{array}$ & Sex & Complain and history & Radiology & Diagnosis & $\begin{array}{l}\text { Procedure and } \\
\text { reconstruction }\end{array}$ \\
\hline 1 & 56 & M & $\begin{array}{l}\text { Left (lt.) orbital swelling due to } \\
\text { subperiosteal abscess, Lynch } \\
\text { and Draf } 1 \text { done } 2009\end{array}$ & $\begin{array}{l}\text { left supraorbital ethmoidal } \\
\text { cell opacity, erosion of } \\
\text { the floor of the F.S. }\end{array}$ & Subperiosteal abscess & $\begin{array}{l}\text { left supraorbital } \\
(\mathrm{SO}) \text { approach } \\
\text { via orbital roof }\end{array}$ \\
\hline 2 & 35 & M & Lt. eye swelling & Opacity of lt. FS \& orbit & Lt. orbital abscess & Lt. SO (orbital roof) \\
\hline 3 & 55 & $\mathrm{M}$ & $\begin{array}{l}\text { Right (Rt.) eye fullness and } \\
\text { proptosis with H/O. RTA } 8 \\
\text { years ago with frontal bone } \\
\text { fracture which repaired }\end{array}$ & $\begin{array}{l}\text { Opacity of Rt. Frontal } \\
\operatorname{sinus(F.S.)}\end{array}$ & Rt. Frontal mucocele & Rt. SO (orbital roof) \\
\hline 4 & 60 & $\mathrm{M}$ & $\begin{array}{l}\text { left frontal swelling, } \\
\text { headach and proptosis }\end{array}$ & $\begin{array}{l}\text { lt.hyperdense } \\
\text { expansile lesion of F.S. } \\
\text { eroding the floor }\end{array}$ & 1t. frontal mucocele & 1t. SO (orbital roof) \\
\hline 5 & 48 & M & $\begin{array}{l}\text { Rt. Frontal swelling, } \\
\text { headach, and proptosis }\end{array}$ & $\begin{array}{l}\text { Totally opacified Rt. } \\
\text { F.S. with thinningout } \\
\text { post. table. }\end{array}$ & $\begin{array}{l}\text { Rt. Frontal mucocele. } \\
\text { Fungal pan sinusitis. }\end{array}$ & $\begin{array}{l}\text { Bil. SO (orbital roof) } \\
\text { combined with Draf } 2 \mathrm{~b}\end{array}$ \\
\hline 6 & 43 & $\mathrm{~F}$ & $\begin{array}{c}\text { Nasal obstruction and left } \\
\text { downward and lateral proptosis. }\end{array}$ & $\begin{array}{l}\text { Opacity of nasal cavity and } \\
\text { sinuses with erosion of the } \\
\text { floor of F.S. far lateral. }\end{array}$ & $\begin{array}{l}\text { allergic fungal sinusitis } \\
\text { AFRS }\end{array}$ & $\begin{array}{l}\text { Bilateral } \mathrm{SO} \text { ( orbit. } \\
\text { roof) combined } \\
\text { with Draf } 2 \mathrm{~b}\end{array}$ \\
\hline 7 & 30 & $\mathrm{~F}$ & Rt. Headache, nasal obst. & Heterogeneous Opacity & AFRS & $\begin{array}{l}\text { Rt. } \mathrm{SO} \text { (roof) } \\
\text { and Draf } 2 \mathrm{~b} \text {. }\end{array}$ \\
\hline 8 & 16 & $\mathrm{M}$ & $\begin{array}{l}\text { RT. CSF rhinorrhea, } \mathrm{H} / \mathrm{O} \\
\text { fall from height }\end{array}$ & $\begin{array}{l}\text { Post. and ant. wall } \\
\text { defect of Rt. FS. }\end{array}$ & $\begin{array}{l}\text { RT. CSF rhinorrhea } \\
\text { After head trauma }\end{array}$ & $\begin{array}{l}\text { Rt. SO (floor) + } \\
\text { Drillout, removal of } \\
\text { fract. bone, cautry of } \\
\text { dura, reco. by f. lata, } \\
\text { fat, middle turb. graft. }\end{array}$ \\
\hline 9 & 15 & $\mathrm{M}$ & $\begin{array}{l}\text { left frontal headache, disfigurement } \\
\text { and downward \& lateral proptosis }\end{array}$ & $\begin{array}{l}\text { an expanding dense } \\
\text { ossifing lesion at } \\
\text { fronto orbital area }\end{array}$ & left frontal osteoma & $\begin{array}{l}\text { Left SO (frontorbital), } \\
\text { reco. by titanium mesh }\end{array}$ \\
\hline 10 & 50 & $\mathrm{~F}$ & $\begin{array}{c}\text { left frontal headache and } \\
\text { downward \& lateral proptosis }\end{array}$ & $\begin{array}{l}\text { an expanding dense } \\
\text { ossifing lesion at } \\
\text { fronto ethmoid }\end{array}$ & left frontal osteoma & $\begin{array}{l}\text { Left SO (frontorbital), } \\
\text { reco. by titanium mesh }\end{array}$ \\
\hline 11 & 60 & $\mathrm{~F}$ & $\begin{array}{l}\text { right frontal swelling and } \\
\text { headache not resp. to med. TTT. }\end{array}$ & $\begin{array}{c}\text { totally opacified rt. F.S. } \\
\text { with eroding anterior table }\end{array}$ & pott's puffy tumour & $\begin{array}{l}\text { Right SO (an. } \\
\text { table). Recon. with } \\
\text { titanium mesh }\end{array}$ \\
\hline 12 & 16 & M & Rt. Frontal swelling, headache & $\begin{array}{l}\text { Total opacification } \\
\text { of Rt. F.S. with } \\
\text { erosion of ant. wall }\end{array}$ & $\begin{array}{l}\text { Rt. pott's puffy } \\
\text { tumour }\end{array}$ & $\begin{array}{l}\text { Rt. SO (ant. table) } \\
\text { reconst. with } \\
\text { titanium mesh }\end{array}$ \\
\hline 13 & 39 & M & $\begin{array}{l}\text { left frontal disfigurement, } \\
\text { headache and downward } \\
\& \text { lateral proptosis }\end{array}$ & $\begin{array}{l}\text { left frontal multilocular } \\
\text { opacity eroding the floor } \\
\text { and anerior table of F.S. }\end{array}$ & $\begin{array}{l}\text { left frontal sinus } \\
\text { mucocele }\end{array}$ & $\begin{array}{l}\text { left SO (frontoorbital } \\
\text {, FO) combined }\end{array}$ \\
\hline
\end{tabular}




\begin{tabular}{|c|c|c|c|c|c|c|}
\hline 14 & 43 & $\mathrm{M}$ & $\begin{array}{l}\text { Recurrent frontal swelling } \\
\& \text { headache. h/o brain } \\
\text { tumour removed through } \\
\text { craniotomy } 2008 \text { complicated } \\
\text { by chronic frontal sinusitis }\end{array}$ & $\begin{array}{l}30 \mathrm{~mm} \text { by } 22 \mathrm{~mm} \\
\text { mucocele in Rt. F.S. } \\
\text { thinned out post. table. }\end{array}$ & $\begin{array}{l}\text { Rt. Frontal mucocele } \\
\text { eroding posterior table }\end{array}$ & $\begin{array}{l}\text { Rt. SO (Frontoorbital) } \\
\text { Combined with Draf 2) }\end{array}$ \\
\hline 15 & 27 & $\mathrm{M}$ & $\begin{array}{c}\text { Nasal obstruction and left } \\
\text { downward and lateral proptosis } \\
\text { with frontal swelling. }\end{array}$ & $\begin{array}{l}\text { Heterogeneous opacity } \\
\text { of F.S. and erosion } \\
\text { of anterior table. }\end{array}$ & $\begin{array}{l}\text { pott's puffy tumour, } \\
\text { fungal sinusitis }\end{array}$ & $\begin{array}{l}\text { left } \mathrm{SO} \text { ( ant. table) } \\
\text { combined with Draf III }\end{array}$ \\
\hline 16 & 9 & $\mathrm{M}$ & $\begin{array}{l}\text { Recurrent headache with fever. } \\
\text { h/o frontal trauma } 5 \text { ys ago with } \\
\text { recurrent attacks of meningitis }\end{array}$ & $\begin{array}{l}\text { CT \& MRI: large defects } \\
10 \mathrm{~mm} \text { by } 12 \mathrm{~mm} \text { at } \\
\text { post. wall of Left F.S }+ \\
\text { meningoencephalocele }\end{array}$ & $\begin{array}{l}\text { meningoencephalocele } \\
\text { at. Lt. F.S. post- } \\
\text { Traumatic }\end{array}$ & $\begin{array}{l}\text { Lt. SO (FO) combined } \\
\text { reconst.by surgicel, } \\
\text { F.lata, fat, F. lata } \\
\text { and mid.turb. graft. }\end{array}$ \\
\hline 17 & 66 & $\mathrm{M}$ & $\begin{array}{l}\text { DLC after operation of } \\
\text { meningioma via parieto } \\
\text { temporal craniotomy }\end{array}$ & $\begin{array}{l}\text { pre: left parieto temporal } \\
\text { craniotomy seen with } \\
\text { defects of posterior and } \\
\text { anterior walls of F.S. } \\
\text { with pneumocephalus }\end{array}$ & $\begin{array}{l}\text { meningitis and } \\
\text { generalized } \\
\text { encephalopathy }\end{array}$ & $\begin{array}{c}\text { Left SO } \\
\text { (miniosteoplastic } \\
\text { flap). reconst. by } \\
\text { pericranial flap, fascia } \\
\text { lata, muscle, fat, } \\
\text { PRF \& tissue glue. }\end{array}$ \\
\hline 18 & 46 & $\mathrm{M}$ & $\begin{array}{l}\text { Left frontal headache. six } \\
\text { Lynch operations done } \\
\text { with no improvement. }\end{array}$ & $\begin{array}{l}\text { CT. total opacity of } \\
\text { F.S., bony defect at left } \\
\text { lacrimal bone and antero } \\
\text { inferior wall of left F.S. }\end{array}$ & $\begin{array}{l}\text { biopsy revealed } \\
\text { inverted papilloma }\end{array}$ & $\begin{array}{c}\text { Combined } \\
\text { SO approach, } \\
\text { miniosteoplastic } \\
\text { flap with endonasal } \\
\text { approach }\end{array}$ \\
\hline 19 & 34 & $\mathrm{M}$ & $\begin{array}{l}\text { LT. eye swelling, proptosis, } \\
\text { headache, nasal obs. } \\
\text { h/o lat. rhinotomy. }\end{array}$ & $\begin{array}{l}\text { Opacity of lt. frontal sinus } \\
\text { extending to the orbit. }\end{array}$ & $\begin{array}{l}\text { 1t. orbital abscess } \\
\text { complicating } \\
\text { frontal I.P. }\end{array}$ & $\begin{array}{l}\text { Combined SO, lt. } \\
\text { osteoplastic flap with } \\
\text { Draf } 2 \text { b. reco. by } \\
\text { pericranial flap, tissue } \\
\text { glue, PRF, surgicel. }\end{array}$ \\
\hline 20 & 26 & $\mathrm{M}$ & $\begin{array}{l}\text { RTA } 5 \text { ys ago with extradural } \\
\text { haematoma with recurrent } \\
\text { attacks of meningitis }\end{array}$ & $\begin{array}{l}\text { Defect at post. } \\
\text { wall of 1t. F.S }\end{array}$ & $\begin{array}{l}\text { left CSF rhinorrhea } \\
\text { after trauma }\end{array}$ & $\begin{array}{l}\text { LT. Combined SO. } \\
\text { (OPF). Reconst. With } \\
\text { fat, F. lata, middle } \\
\text { turb. \& tissue glue }\end{array}$ \\
\hline
\end{tabular}

\section{DISCUSSION}

Frontal sinus surgery is the most challenging aspect of endoscopic sinus surgery. The complex anatomy, acute nasofrontal angle, and proximity to critical structures such as the skull base, olfactory fossa, and orbit all contribute to the surgical difficulty ${ }^{[4]}$.

Endoscopic sinus surgery (ESS) can successfully manage most inflammatory disorders, cerebrospinal fluid (CSF) leak, severe epistaxis, benign tumors, and confined malignancies of the nose, sinuses, and skull base.

This study has adopted a direct approach to the frontal sinus and anterior skull base lesions through supraorbital approach with the aid of an endoscope to allow for wide visualization of lateral and midline lesions in the anterior cranial fossa. With the miniorbitofrontal craniotomy, the working corridor runs along the skull base. As a result, intradural lesions can be accessed without requiring extensive and prolonged frontal lobe retraction. While lesions located extremely anterior and lateral along the anterior skull base may be difficult to access via a transnasal endoscopic approach, they can be easily reached through supraorbital approach ${ }^{[5]}$.

The type and extent of craniotomy were tailored based on the location of the targeted pathology. The craniotomy can be limited to the orbital roof or it can extend along the anterior wall of the frontal sinus and 
superior orbital ridge without violating the floor of the frontal sinus. The craniotomy window can be extended medially toward the midline if exposure and access to both frontal sinuses are desired ${ }^{[5]}$.

The current study aimed to evaluate the efficacy and safety of the supraorbital approach in the management of extensive frontal sinus lesions. This was based on preoperative imaging studies and intraoperative findings. The study group included 20 patients with three pathological categories: inflammatory (60\%), neoplastic (20\%), and CSF leak (20\%).

\section{I- Inflammatory lesions:}

The inflammatory frontal sinus pathologies included $12 / 20$ cases divided into five cases of acute complicated frontal sinusitis (two cases of subperiosteal abscess and three cases of frontal bone osteomyelitis) and seven cases of chronic fronta sinusitis; mucocele was present in 5/7 cases and allergic fungal rhinosinusitis (AFRS) was present in 2/7 cases.

\section{I.1 Acute complicated sinusitis:}

All patients had their empyematous frontal sinuses drained. In both cases of subperiosteal abscess, the necrotic tissues were removed and the secretions were suctioned through the orbital roof window, then the sinus was drained and irrigated with normal saline. While the three cases of PPT were approached through the anterior table in which the necrotic bone was completely removed from the anterior wall of the frontal sinus (what is called a craniectomy), inflamed mucosa and putrid secretions were removed from its lumen, and a wide drain into the nasal cavity was created with the assistance of Draf $2 b$ from below. Finally, a titanium mesh was used to reconstruct the anterior wall defect, which was more than one centimeter.

The five patients were continued on medical treatment in the form of clindamycin for 2-4 weeks and were followed up on a regular basis for two years, with improvement of their complaints without complications or recurrence.

Gassner et al. demonstrated that patients with sinogenic complications can be successfully treated in a minimally invasive manner using a trans-supraorbital approach without significant risks ${ }^{[6]}$.

\section{I.2 Chronic inflammatory lesions:}

\section{I.2.1 Mucoceles:}

This approach was used to treat mucoceles that were far lateral or multiloculated, located in a supraorbital air cell, or that were eroding either the anterior or posterior table of the frontal sinus and could not be addressed via the endonasal approach alone. These lesions were surgically removed through the orbital roof window in three cases (because the mucoceles eroded the orbital roof, which was just enlarged enough to allow for good removal of the mucoceles) and through the frontal mini-craniotomy in two cases (where the mucoceles eroded the anterior and posterior table, so more space was needed to assess the frontal dura). Three cases were managed in combination with Draf $2 b$ to ensure permanent sinus drainage and prevent recurrence.

During the follow-up, the patients' complaints had subsided, and there were no complications or evidence of recurrence.

A study published by Martel-Martin et al. included 32 patients with fronto-ethmoidal mucoceles; 15 cases $(46.8 \%)$ required an endonasal approach, 17 cases $(53.2 \%)$ required an external approach, and 10/17 cases required a combined approach. There were no major postoperative complications ${ }^{[7]}$.

\section{I.2.2 Allergic Fungal Rhinoinusitis (AFRS):}

Both patients of AFRS underwent supraorbital approach via orbital roof window combined with Draf $2 \mathrm{~b}$ for clearance of the disease from above and below. They were given antibiotics for one week as well as oral steroids, which were tapered post-operatively over three weeks.

During the follow-up, the patients' complaints disappeared, and a computed tomography scan was performed one month after surgery to look for residual disease, which revealed none. There were no complications or evidence of a recurrence.

Gupta and Gupta conducted a study on AFRS using an endonasal approach, and the success rate was $(82.25$ $\%)$. A recurrence occurred in three patients (18.75\%). They had difficulties in removing the disease from the most lateral region of the frontal sinus which may need an external approach ${ }^{[8]}$.

\section{II- Neoplastic Lesions:}

Four cases of neoplastic lesions were presented: two cases of fronto-orbital osteoma and two cases of inverted papilloma.

\section{II.1 Osteoma}

Chiu et al. devised a grading system for osteomas to provide guidelines for surgical management. The grading was based on the location of the base of 
attachment, location in relation to a virtual sagittal plane through the lamina papyracea, and the anteriorposterior diameter of the osteoma in relation to the anterior-posterior diameter of the frontal recess. Their recommendation was to adopt the external approach for grade III and IV osteomas and the endoscopic approach for grade I and II osteomas ${ }^{[9]}$.

Grade III and IV osteomas that occupy more than $75 \%$ of the frontal sinus, have significant posterior table erosion, have a history of meningitis or CSF leak, have extensive intracranial extension, and have a significant supraorbital component with lateral orbital mucoceles pose a significant challenge to the endoscopic approach. Even in the endoscopic era, certain osteomas are best approached directly and safely through the external approach ${ }^{[10]}$.

The two cases of frontal osteoma (grade IV) were managed through eyebrow incision with extension of the incision inferomedially (Lynch-Howarth) in one case (\#10). The osteoma itself eroded the anterior table, and the defect that resulted from the removal of such a large osteoma was reconstructed with a titanium mesh fixed with proline sutures.

The two patients were followed up on, and their symptoms improved, with only one early complication in the form of supraorbital parasthesia (supratrochlear and supraorbital nerve injuries) occurring in one patient (\# 10), which resolved six months later. Other complications or recurrences did not occur.

Chahed et al. reported a series of 44 patients with frontal osteomas. The overall complication rate was $11.1 \%$. A dural breach was reported in three cases. A section of the lacrymal duct was recorded in two patients. Two recurrences were observed and were reoperated on via osteoplastic flap ${ }^{[1]}$.

\section{II.2 Inverted papilloma}

The mode of involvement of the frontal sinus is one of the most critical issues in surgery for inverted papilloma. A Draf IIa was performed when the inverted papilloma extended fingerlike from the ethmoid into the frontal recess and/or sinus. A Draf IIb was used whenever the inverted papilloma was found to originate at the level of the frontal recess. A Draf III was used in patients with lesions arising from the mucosa of the posterior wall of the frontal sinus. An external approach was required whenever there was extensive mucosal involvement inside a supraorbital cell extending far laterally over the orbit or a massive involvement of the frontal sinus mucosa ${ }^{[12]}$.

The current study included two cases of inverted papilloma. One patient (\# 19) presented with an orbital abscess that had to be drained externally before definitive treatment. The tumors extended into the frontal recess and the hyperneumatised frontal sinus far laterally with erosion of the orbital roof. Because the tumor could not be completely addressed via endonasal approach alone, it was removed via supraorbital approach by elevating the anterior wall of the sinus as a mini osteoplastic flap combined with Draf $2 b$ to remove the tumor from above and below, drilling the underlying bone, and removing the interfrontal sinus septum. Finally, the osteoplastic flap was returned and fixated with sutures.

The patients were followed up on, and CT revealed that the pathology had been completely removed, with no residuals or complications, as well as good healing of the osteoplasic flap and no recurrence.

Nicolai et al. published their findings from a series of 98 patients, stating that whenever a lesion involves the anterior wall or lateral part of an extensively pneumatized frontal sinus, the surgeon must combine an external approach to remove the diseased mucosa while drilling the underlying bone in those areas that are not accessible from below ${ }^{[13]}$.

Walgama et al. published a systematic review of 13 studies involving 49 patients. Endoscopic frontal sinusotomy was used in 21 patients $(42.9 \%)$, endoscopic modified Lothrop in ten patients (20.4 $\%)$, osteoplastic flap in 13 patients $(26.5 \%)$, and trephination in five patients $(10.2 \%)$. The overall recurrence rate was $(22.4 \%)^{[14]}$.

Ibrahim et al. treated ten patients of IP. In one year and four months, five combined surgeries (endonasal with OPF) and five extended endoscopic endonasal surgeries were performed, with a two-year follow-up period. The results showed a global success rate of $100 \%{ }^{[15]}$.

\section{III-CSF leaks:}

The majority of anterior cranial base defects and associ-ated cerebral spinal fluid (CSF) leaks are currently repaired by the endoscopic transnasal approach. Neverthe $\neg$ less, frontal sinus CSF leaks, especially far lateral, posterior, and superiorly located leaks, remain difficult to access with transnasal endoscopic techniques. These frontal sinus-re $\neg$ lated CSF leaks are traditionally approached through a bi $\neg$ coronal incision and variations of frontotemporal cranioto $\neg$ mies. With the increasing push for minimally invasive procedures, the supraorbital craniotomy approach has increased in popularity as a minimal access modification of the traditional orbitofron $\neg$ tal craniotomy to access anterior cranial base lesions and $\operatorname{defects}^{[16]}$ 
When the leak (at the mid-orbital level) was in the medial part of the posterior wall of the frontal sinus, it would be addressed endoscopically through Draf IIb and Draf III. On the other hand, when the leak (at the mid-orbital level) was in the lateral part of the posterior wall of the frontal sinus; a combined approach was attempted $^{[17]}$.

In the current study, 4 cases of CSF leaks were included. The location of the defect, involving the posterior wall of the frontal sinus, was determined to be beyond easy access with a transnasal endoscopic approach.

The CSF leaks were repaired with a brow incision and a mini fronto-orbital craniotomy. Three cases were managed as "above and below" to address the defect and repair using the middle turbinate. In terms of the dural repair technique, double layers of fascia lata were used in traumatic CSF. The graft is then fixed to the dura or within the dural defect with fibrin glue. The repair was then reinforced with a fat and middle turbinate graft. In a case of iatrogenic CSF, pericranial flap, fascia lata, platelet-rich fibrin (PRF), and tissue glue were used for reconstruction.

There were no complications or evidence of CSF leak at the follow-up, and the brow healed with excellent cosmetic results and no recurrence.

In the study by Moe et al., ten patients with CSF leaks underwent endoscopic CSF leak repair via superior orbital roof craniotomy. They used double layers of allogenic dermis to repair the dural defects. All of the procedures were successful and there were no recurrences of CSF leak. There were no significant complications in the series ${ }^{[18]}$.

The main early complication encountered in the current study was supraorbital parasthesia (supratrochlear and supraorbital nerve injuries) in one patient (\#10), which was resolved within six months. There were no late complications or signs of disease recurrence until the end of the follow-up period.

Suarez et al. reported in a study on the management of frontal sinus lesions using different approaches that, while frontal paresthesias are common in external frontal sinus approaches, they usually resolve within three months ${ }^{[19]}$

\section{CONCLUSIONS}

Through a mini-craniotomy, the supraorbital approach allows for wide access to the frontal sinus and anterior skull base. The adjunctive use of the endoscope broadens the working corridor to include the entire posterior frontal sinus wall.
The supraorbital approach to the anterior skull base and frontal sinus lesions is a safe, direct, and minimally invasive approach that should be considered as an alternative to more extensive craniofacial approaches for selected frontal sinus and anterior skull base pathologies.

\section{RECOMMENDATIONS}

The surgeon should be versatile and tailor the approach according to the site and extent of the pathology. The surgeon can change his surgical strategy intraoperatively and should be ready and well equipped to shift from one approach to the other.

If conversion to an open approach is being considered, expertise with trephine, osteoplastic flaps, as well as different incision types such as brow, hairline, and coronal are needed and a comprehensive pre-operative discussion of the risks and benefits of each approach should be performed.

External frontal sinus approaches should always be considered as a backup plan for lesions affecting the frontal sinus extensively or extending far laterally.

\section{CONFLICT OF INTEREST}

There are no conflicts of interest.

\section{ACKNOWLEDGEMENT}

I wish to express my sincere thanks to my colleague, Dr. Haitham Morsy, MD Otorhinolaryngology, Alexandria University, and my dear friend Dr. abdelrahman Younes Ali, assistant professor of Otorhinolaryngology, Kasr Al-Ainy Faculty of Medicine, Cairo university, for their continuous help, guidance and support throughout the work.

\section{REFERENCES}

1. Raza, S. M., Quinones-Hinojosa, A., Lim, M. \& Boahene, K. D. O. The Transconjunctival Transorbital Approach: A Keyhole Approach to the Midline Anterior Skull Base. World Neurosurgery.2013; 80, 864-871.

2. Snyderman, C. H., Pant, H., Carrau, R. L., Prevedello, D., Gardner, P. \& Kassam, A. B. What Are The Limits Of Endoscopic Sinus Surgery: The Expanded Endonasal Approach To The Skull Base. The Keio Journal of Medicine.2009; 58, 152-160.

3. Knopman, J., Sigounas, D., Huang, C., Kacker, A., Schwartz, T. \& Boockvar, J. Combined Supraciliary And Endoscopic Endonasal Approach For Resection Of Frontal Sinus Mucoceles. Min-Minimally Invasive Neurosurgery. 2009; 52, 149-151. 
4. Naidoo Y, Wen D, Bassiouni A, Wormald PJ. Longterm results after primary frontal sinus surgery. Int Forum Allergy Rhinol. 2012; 2(3):185-90.

5. Boahene, K. D. O., Lim, M., Chu, E. \& QuinonesHinojosa, A. Transpalpebral Orbitofrontal Craniotomy: A Minimally Invasive Approach to Anterior Cranial Vault Lesions. Skull Base. 2010; 20, 237-244.

6. Gassner, H. G., Schwan, F. \& Schebesch, K.M. Minimally Invasive Surgery Of The Anterior Skull Base: Transorbital Approaches. Current Topics in Otorhinolaryngology, Head and Neck Surgery. 2015; 14

7. Martel-Martín, M., Gras-Cabrerizo, J. R., BotheGonzález, C., et al. Clinical Analysis and Surgical Results of 58 Paranasal Sinus Mucoceles. Acta Otorrinolaringologica (English Edition). 2015; 66, 92 97.

8. Gupta, R. \& Gupta, A. Isolated Primary Frontal Sinus Aspergillosis: Role Of Endonasal Endoscopic Approach. The Journal Of Laryngology \& Otology.2013; 127, 274-278.

9. Chu, E. A., Quinones-Hinojosa, A. \& Boahene, K. D. O. Trans-Blepharoplasty Orbitofrontal Craniotomy For Repair Of Lateral And Posterior Frontal Sinus Cerebrospinal Fluid Leak. Otolaryngology-Head And Neck Surgery.2010; 142, 906-908.

10. Rokade, A. \& Sama, A. Update On Management Of Frontal Sinus Osteomas. Current Opinion In Otolaryngology \& Head And Neck Surgery.2012; 20, 40-44.

11. Chahed, H., Hachicha, H., Marrakchi, J., Mediouni, A., et al. Paranasal Sinus Osteomas: Diagnosis and Treatment. Revue De Stomatologie, De Chirurgie Maxillo-Faciale Et De Chirurgie Orale.2016; 117, 306-310.
12. Lombardi, D., Tomenzoli, D., Butta, L., Bizzoni, A. Farina, D., Sberze, F., Karligkiotis, A., Castelnuovo, P. \& Nicolai, P. Limitations And Complications Of Endoscopic Surgery For Treatment For Sinonasal Inverted Papilloma: A Reassessment After 212 Cases. Head \& Neck.2011; 33, 1154-1161.

13. Nicolai, P., Tomenzoli, D., Lombardi, D. \& Maroldi, R. Different Endoscopic Options In The Treatment Of Inverted Papilloma. Operative Techniques In Otolaryngology-Head And Neck Surgery. 2006);17, 80-86.

14. Walgama E, Ahn C, Batra PS. Surgical management of frontal sinus inverted papilloma: a systematic review. Laryngoscope. 2012;122:1205-9

15. Ibrahim, A., Morsi, H., Hassab, M., Eid, M. \& Elwany, S. Surgical strategy for frontal sinus inverted papilloma. Egyptian Journal Of Ear, Nose, Throat And Allied Sciences.2017; 18, pp.241-246.

16. Chu, E. A., Quinones-Hinojosa, A. \& Boahene, K. D. O. Trans-Blepharoplasty Orbitofrontal Craniotomy For Repair Of Lateral And Posterior Frontal Sinus Cerebrospinal Fluid Leak. Otolaryngology-Head And Neck Surgery. 2010; 142, 906-908.

17. Conger Jr, B. T., Riley, K. \& Woodworth, B. A. The Draf III mucosal grafting technique: a prospective study. Otolaryngology--Head and Neck Surgery. 2012; 146, 664-668

18. Moe, K. S., Bergeron, C. M. \& Ellenbogen, R. G. Transorbital Neuroendoscopic Surgery. Operative Neurosurgery. 2010; 67, 16-28.

19. Suárez, C., Obeso, S., Llorente, J. L., Rodrigo, J. P., Sánchez, R. \& Mancebo, G. Mucoceles De Senos Paranasales. Nuestra Experiencia En 72 Pacientes. Acta Otorrinolaringologica Espanola.2009, 60, 332-339. 